\title{
Relationship between Nutritional Status and Physical Freshness Levels with Learning Outcomes of Physical, Sports and Health Education
}

\author{
Djoni Rumondor ${ }^{1}$, Christianti Anggraini Motto ${ }^{1}$, Mareike Doherty Patras ${ }^{2}$ \\ ${ }^{1}$ Universitas Negeri Manado, Indonesia \\ ${ }^{2}$ Lecturer in Politeknik Negeri Nusa Utara, Indonesia \\ Email: djonirumondor@unima.ac.id
}

\begin{abstract}
This study aims to determine relationship between nutritional status and physical freshness levels with learning outcomes of physical, sports and health education. This research is a descriptive study with correlation techniques. This research is conducted at Junior High School I of Tondano, Sangihe Islands, North Sulawesi Province. Based on the results of research and discussion, some conclusions can be drawn as follows: 1) There is a relationship between nutritional status with learning outcomes of physical, sports and health education in Junior High School students I of Tondano; 2) There is a relationship between physical freshness with learning outcomes of physical, sports and health education in Junior High School students I of Tondano; 3) There is a relationship between nutritional status and physical freshness together with learning outcomes of physical, sports and health education in Junior High School students I of Tondano.

Keywords: nutritional status; physical freshness levels; learning outcomes
\end{abstract}

\section{Introduction}

Sports and health physical education will provide opportunities for students to develop knowledge and skills related to physical activities, and social development. Developing the confidence and the ability to master basic movement skills that will encourage participation in physical activity. Obtain and maintain an optimal degree of physical freshness to carry out daily tasks efficiently and in a controlled manner. Developing values through participation in physical activities both in groups and individually. Participate in activities that can, develop social skills that enable students to function effectively in relationships between people. Enjoy the fun and excitement through physical activities including sports games.

Seeing the importance of the role and sports and health physical education of students for the government so that the government continues to fix educational sports infrastructure suggestions in accordance with the level of need, this is in order to meet eight national education standards where one is the standard means to achieve the goals of sports education itself, especially in sports coaching and development achievement.

The level of physical freshness and nutritional index of students are two very determining factors in fostering sports achievement, physical freshness and nutritional index greatly affect the performance of athletes in achieving sports achievements. Nutritional status is food substances contained in food that can be utilized by the body. From food substances affect the physical state or physical work done by someone. Because the food will be obtained nutrients which will produce energy that is burned in the cells of the body to support daily activities in addition to building parts of the body, and metabolic processes in the body. Nutritional status is a factor that influences energy needs and nutritional status, so students who have a state of underweight or high nutritional status need a diet program to improve (Anonymous, 1993: 5). 
Physical freshness is a physical condition that describes physical ability, which is the ability of a person to do certain jobs quite well without causing fatigue. Physical freshness is a physical aspect of overall freshness that gives a person the ability to lead a productive life and can adjust to each physical burden. (Anonymous, 2008: 59)

Student of Junior High School I of Tondano is an age group of growth both physically and psychologically. Of the two growths is greatly influenced by many factors including physical freshness and nutritional status, understanding the level of physical freshness and nutritional status obtained from teaching materials on Physical Education subjects. It is hoped that students will understand their condition from lessons learned at face-to-face (curricular) meetings and extracurricular activities.

\section{Review of Literature}

Good nutritional status is very necessary to obtain excellent physical condition. Nutritional status can be assessed by several examinations namely:

a. Clinical examination Clinical examination to determine the presence or absence of certain nutritional deficiencies.

b. Anthropometric measurements Measurement of height, weight, fat thickness; triceps, biceps, subscapula and suprailliaca.

c. Laboratory examination (biochemistry)

Especially hemoglobin, other tests can also be done such as ferritin, glucose, cholesterol and others.

d. Assessment of food consumption

Can be done through interviews of eating habits and calculation of daily food consumption.

Of all the common and easy ways to assess nutritional status, is anthropometric measurements. This measurement can be carried out by someone who has been given training, while other nutritional status assessment methods require special expertise such as doctors, nutritionists, analysis, etc.

\subsection{Anthropometric Measurements}

Some simple and common measurements are used to assess nutritional status in adults: a. Weight
a) Weighing an athlete's weight is one way to evaluate the balance of energy intake with activity. Athletes need to weigh regularly before and after training.
b) Weighing is done with minimal clothing, and the body is not sweating.
c) The instrument used is "Beam Balance" with accuracy of $100 \mathrm{gr}$.

\section{b. Height}

a) Measurement of height is needed as a parameter of nutritional status based on body weight to height.

b) Measurements is made with an upright stance without shoes.

c) Measuring devices: use a flexible and non-elastic centimeter pattern that is affixed vertically on a wall / upright pole or height measuring instrument "Microtoise".

\section{c. Upper Arm Circumference}

a) Upper arm circumference size indicates muscle mass

b) Measuring at the point in the middle of the shoulder sign and elbow bump with the position of the relaxed upper arm hanging. 
c) Measuring instrument: Using a centimeter pattern that is flexible and not elastic, looped on Li-A.

\section{d. Skin Fold Thickness (SFT)}

a) SFT measurements show body fat mass and body composition.

b) Measurements are made in the area: triceps, biceps, sub scapula, supra illiaca.

c) The instrument used, Skin Fold Caliper with an accuracy of $0.1 \mathrm{~mm}$.

Mass body fat is calculated as a percentage of body weight by adding up the thickness of the skin folds.

\subsection{Improvement of Nutritional Status}

The goals of food regulation include efforts to:

- Improve nutritional status, among others: gain weight, increase Hb levels.

- Lose weight, especially athletes who require sports branch weight classification.

\section{a. Food to Improve Nutritional Status}

Things that need to be considered

a) Energy and nutrient requirements are determined according to age, weight, sex and activity. In growth-age athletes whose nutritional status is poor, protein requirements are higher than in adulthood.

b) The composition of a balanced menu, derived from a variety of food ingredients, using a list of food ingredients exchangers (appendix 4), vitamins and minerals as needed.

c) The menu is adjusted to the diet based on the results of a diet interview conducted, and the distribution of food is adjusted to the schedule of activities.

d) To increase $\mathrm{Hb}$ levels, some examples of iron-rich foods can be seen in table 2.5. Iron derived from animal food, is absorbed more by the body than food derived from vegetable:

Table 1. Iron Source Foodstuffs

\begin{tabular}{|ll|}
\hline Foodstuffs per $100 \mathrm{gr}$ & Zat Besi mg. \\
\hline Animal: & \\
- rendang meat & 14,6 \\
- fried chicken breast & 7,5 \\
- turtle satay & 14,4 \\
- dendeng teripang & 96,4 \\
- dendeng belut & 16,6 \\
- dendeng mujair fish & 7,4 \\
- dendeng goldfish & 6,1 \\
- duck egg & 5,5 \\
- banjar fish & 7,3 \\
- calo peda & 22,6 \\
- clam & 15,6 \\
Vegetable: & \\
- pure fried tempe & 4,9 \\
- boiled tolo beans & 13,9 \\
- fresh red beans & 3,7 \\
- steamed spinach & 5,7 \\
- long beans & 3,7 \\
- katu leaf & $3, \mathrm{~s}$ \\
- swamp cabbage & 4,4 \\
- Sago Ambon & 10,9 \\
\hline
\end{tabular}


In addition to increasing consumption of foods rich in iron, it is also necessary to add a lot of food. Contains vitamin $\mathrm{C}$ such as papaya, oranges, pineapple, green bananas, wani fruit, sapodilla, breadfruit, etc.

\section{Research Method}

This research is a descriptive study with correlation techniques. This research is conducted at Junior High School I of Tondano, Sangihe Islands, North Sulawesi Province.

\section{Discussion}

\subsection{Description of Measurement Data}

From the results of measurements on the variable power arm $\left(\mathrm{X}_{1}\right)$ and balance $\left(\mathrm{X}_{2}\right)$ with the ability to reject bullets $(\mathrm{Y})$ in basketball games can be seen in the following table.

Table 2. Measurement Results Variables X1, X2 and Y

\begin{tabular}{|c|c|c|c|}
\hline No & Power arm & Balance & Shot put \\
\hline 1 & 29 & 14 & 820 \\
\hline 2 & 24 & 12 & 795 \\
\hline 3 & 26 & 13 & 802 \\
\hline 4 & 25 & 8 & 786 \\
\hline 5 & 17 & 7 & 790 \\
\hline 6 & 17 & 7 & 794 \\
\hline 7 & 27 & 11 & 813 \\
\hline 8 & 19 & 5 & 790 \\
\hline 9 & 25 & 13 & 820 \\
\hline 10 & 29 & 14 & 780 \\
\hline 11 & 20 & 14 & 831 \\
\hline 12 & 25 & 7 & 811 \\
\hline 13 & 19 & 11 & 812 \\
\hline 14 & 19 & 6 & 772 \\
\hline 15 & 23 & 6 & 770 \\
\hline 16 & 23 & 8 & 810 \\
\hline 17 & 23 & 6 & 772 \\
\hline 18 & 27 & 11 & 783 \\
\hline 19 & 26 & 8 & 790 \\
\hline 20 & 20 & 9 & 784 \\
\hline 21 & 18 & 9 & 785 \\
\hline 22 & 20 & 10 & 765 \\
\hline 23 & 21 & 12 & 840 \\
\hline 24 & 26 & 10 & 830 \\
\hline 25 & 17 & 9 & 810 \\
\hline 26 & 22 & 6 & 770 \\
\hline 27 & 21 & 10 & 797 \\
\hline 28 & 20 & 9 & 834 \\
\hline
\end{tabular}


Britain International of Linguistics, Arts and Education (BIoLAE) Journal ISSN: 2685-4813 (Online), 2685-4805 (Print)

Vol. 1, No. 2, November 2019, Page: 303-316

\begin{tabular}{|l|l|l|l|}
\hline 29 & 17 & 10 & 837 \\
\hline 30 & 19 & 12 & 833 \\
\hline
\end{tabular}

From the measurement results in table 2, further assisted by using the Casio $\mathrm{fx} 3600 \mathrm{p}$ Calculator obtained prices both on variable $\mathrm{X}_{1}$, variable $\mathrm{X}_{2}$ and variable $\mathrm{Y}$ for analysis purposes, as follows.

$\begin{aligned} \mathrm{n} & =30 & & \\ \sum \mathrm{X}_{1} & =664 & \sum \mathrm{X}_{1}^{2} & =15096 \\ \sum \mathrm{X}_{2} & =287 & \sum \mathrm{X}_{2}^{2} & =2953 \\ \sum_{\mathrm{Y}} \mathrm{Y} & =24026 & \sum^{2} & =19256442 \\ \mathrm{X}_{1} & =22,13 & \mathrm{Sdx}_{1} & =3,71 \\ \overline{\mathrm{X}}_{2} & =9,56 & \mathrm{Sdx}_{2} & =2,26 \\ \overline{\mathrm{Y}} & =800,86 & \mathrm{Sd}_{\mathrm{y}} & =2,67\end{aligned}$

Table 3. T-Score Data Measurement of Variables $\mathrm{X}_{1}, \mathrm{X}_{2}$ and $\mathrm{Y}$

\begin{tabular}{|c|c|c|c|c|c|c|}
\hline No & $\mathbf{X}_{1}$ & $\mathbf{X}_{2}$ & $\mathbf{Y}$ & T-Score $\mathrm{Xi}$ & T-Score $\mathrm{X}_{2}$ & T-Score $Y$ \\
\hline 1 & 29 & 14 & 820 & 68.52 & 66.63 & 58.50 \\
\hline 2 & 24 & 12 & 795 & 55.04 & 59.14 & 47.43 \\
\hline 3 & 26 & 13 & 802 & 60.43 & 62.88 & 50.53 \\
\hline 4 & 25 & 8 & 786 & 57.74 & 44.16 & 43.45 \\
\hline 5 & 17 & 7 & 790 & 36.17 & 40.41 & 45.22 \\
\hline 6 & 17 & 7 & 794 & 36.17 & 40.41 & 46.99 \\
\hline 7 & 27 & 11 & 813 & 63.13 & 55.39 & 55.40 \\
\hline 8 & 19 & 5 & 790 & 41.56 & 32.92 & 45.22 \\
\hline 9 & 25 & 13 & 820 & 57.74 & 62.88 & 58.50 \\
\hline 10 & 29 & 14 & 780 & 68.52 & 66.63 & 40.80 \\
\hline 11 & 20 & 14 & 831 & 44.26 & 66.63 & 63.36 \\
\hline 12 & 25 & 7 & 811 & 57.74 & 40.41 & 54.51 \\
\hline 13 & 19 & 11 & 812 & 41.56 & 55.39 & 54.96 \\
\hline 14 & 19 & 6 & 772 & 41.56 & 36.67 & 37.26 \\
\hline 15 & 23 & 6 & 770 & 52.35 & 36.67 & 36.37 \\
\hline 16 & 23 & 8 & 810 & 52.35 & 44.16 & 54.07 \\
\hline 17 & 23 & 6 & 772 & 52.35 & 36.67 & 37.26 \\
\hline 18 & 27 & 11 & 783 & 63.13 & 55.39 & 42.12 \\
\hline 19 & 26 & 8 & 790 & 60.43 & 44.16 & 45.22 \\
\hline 20 & 20 & 9 & 784 & 44.26 & 47.90 & 42.57 \\
\hline 21 & 18 & 9 & 785 & 38.87 & 47.90 & 43.01 \\
\hline 22 & 20 & 10 & 765 & 44.26 & 51.65 & 34.16 \\
\hline 23 & 21 & 12 & 840 & 46.95 & 59.14 & 67.35 \\
\hline 24 & 26 & 10 & 830 & 60.43 & 51.65 & 62.92 \\
\hline 25 & 17 & 9 & 810 & 36.17 & 47.90 & 54.07 \\
\hline 26 & 22 & 6 & 770 & 49.65 & 36.67 & 36.37 \\
\hline 27 & 21 & 10 & 797 & 46.95 & 51.65 & 48.32 \\
\hline 28 & 20 & 9 & 834 & 44.26 & 47.90 & 64.69 \\
\hline 29 & 17 & 10 & 837 & 36.17 & 51.65 & 66.02 \\
\hline 30 & 19 & 12 & 833 & 41.56 & 59.14 & 64.25 \\
\hline
\end{tabular}


From the measurement results in table 3 , then assisted by using the Casio $\mathrm{fx} 3600 \mathrm{p}$ Calculator obtained prices both on variable $\mathrm{X}_{1}$, variable $\mathrm{X}_{2}$ and variable $\mathrm{Y}$ for analysis, as follows.

$$
\begin{aligned}
\mathrm{n} & =30 \\
\sum \mathrm{X}_{1} & =1500.27 \\
\sum \mathrm{X}_{2} & =1500,88 \\
\sum \mathrm{Y}_{\mathrm{Y}} & =1500,75 \\
\mathrm{X}_{1} & =50,009 \\
\overline{\mathrm{X}}_{2} & =50,029 \\
\overline{\mathrm{Y}} & =50,025 \\
\mathrm{Sdx}_{1} & =10,02 \\
\mathrm{Sdx}_{2} & =10,002 \\
\mathrm{Sd}_{\mathrm{y}} & =10,015 \\
\sum \mathrm{X}_{1}^{2} & =77929,2 \\
\sum \mathrm{Y}^{2} & =77983,7
\end{aligned}
$$

$$
\begin{aligned}
\sum \mathrm{X}_{1}{ }^{2} & =78008,33 \\
\sum \mathrm{X}_{2}{ }^{2} & =77990 \\
\sum \mathrm{Y}^{2} & =77037,08 \\
\sum \mathrm{X}_{1} \mathrm{Y} & =76168,8 \\
\sum \mathrm{X}_{2} \mathrm{Y} & =76555,4 \\
\left(\sum \mathrm{X}_{1}\right)^{2} & =2250810,073 \\
\left(\sum \mathrm{X}_{2}\right)^{2} & =2252640,774 \\
\left(\sum \mathrm{Y}\right)^{2} & =2252250,563 \\
\left(\sum \mathrm{X}_{2}\right)^{2} & =2260602,461
\end{aligned}
$$

\subsection{Data Processing}

To determine the appropriate statistical techniques in testing research hypotheses, it is necessary to test the analysis requirements that must be met in correlation analysis, namely the normality test and the linearity test.

\section{a. Normality Testing}

Lilliefor Test is one of the normality tests used to test whether the sample is from a normally distributed population. Considering that the variables that are linked have the same pair of the same subject, the writer only needs to take one of the variables analyzed in the normality test, which is arm muscle strength data. The testing steps are as follows.

First: Determine the Hypothesis

Testing Hypothesis:

$\mathrm{H}_{\mathrm{o}}$ : Samples come from populations that are normally distributed

$\mathrm{H}_{\mathrm{a}}$ : samples come from populations that are not normally distributed

Second: Determine Testing Criteria

Thank $\mathrm{H}_{\mathrm{o}}$ if; $\mathrm{Lo} \leq \mathrm{L}_{\text {tab }}$ or.

Reject $\mathrm{H}_{\mathrm{o}}$ if; $\mathrm{Lo}>\mathrm{L}_{\text {tab }}$

Third: Calculate the values of Zi, F (zi) and S (zi) and enter into the following table. For the purposes of testing this normality, the average values and standard deviations are first known. As the data values based on table 1 note the average arm power $(\mathrm{X} 1)=39.435$ and the standard deviation $(\mathrm{Sd} 1)=2.177$.

Table 4. Calculation of Normality Test

\begin{tabular}{|l|l|l|l|l|l|}
\hline $\mathbf{N o}$ & $\mathbf{X i}$ & $\mathbf{Z i}$ & $\mathbf{F}(\mathbf{Z i})$ & $\mathbf{S}(\mathbf{Z i})$ & $\mathbf{F}(\mathbf{Z i})-\mathbf{S}(\mathbf{Z i})$ \\
\hline 1 & 36.17 & -1.38 & 0.0336 & 0.133333 & -0.09973 \\
\hline 2 & 36.17 & -1.38 & 0.0336 & 0.133333 & -0.09973 \\
\hline 3 & 36.17 & -1.38 & 0.0336 & 0.133333 & -0.09973 \\
\hline 4 & 36.17 & -1.38 & 0.0336 & 0.133333 & -0.09973 \\
\hline 5 & 38.87 & -1.11 & 0.1335 & 0.166667 & -0.03317 \\
\hline 6 & 41.56 & -0.84 & 0.2005 & 0.3 & -0.0995 \\
\hline 7 & 41.56 & -0.84 & 0.2005 & 0.3 & -0.0995 \\
\hline
\end{tabular}


Britain International of Linguistics, Arts and Education (BIoLAE) Journal

ISSN: 2685-4813 (Online), 2685-4805 (Print)

Vol. 1, No. 2, November 2019, Page: 303-316

\begin{tabular}{|l|l|l|l|l|l|}
\hline 8 & 41.56 & -0.84 & 0.2005 & 0.3 & -0.0995 \\
\hline 9 & 41.56 & -0.84 & 0.2005 & 0.3 & -0.0995 \\
\hline 10 & 44.26 & -0.57 & 0.2843 & 0.433333 & $\mathbf{- 0 . 1 4 9 0 3}$ \\
\hline 11 & 44.26 & -0.57 & 0.2843 & 0.433333 & $\mathbf{- 0 . 1 4 9 0 3}$ \\
\hline 12 & 44.26 & -0.57 & 0.2843 & 0.433333 & $-\mathbf{0 . 1 4 9 0 3}$ \\
\hline 13 & 44.26 & -0.57 & 0.2843 & 0.433333 & $\mathbf{- 0 . 1 4 9 0 3}$ \\
\hline 14 & 46.95 & -0.31 & 0.3783 & 0.5 & -0.1217 \\
\hline 15 & 46.95 & -0.31 & 0.3783 & 0.5 & -0.1217 \\
\hline 16 & 49.65 & -0.04 & 0.484 & 0.533333 & -0.04933 \\
\hline 17 & 52.35 & 0.23 & 0.591 & 0.633333 & -0.04233 \\
\hline 18 & 52.35 & 0.23 & 0.591 & 0.633333 & -0.04233 \\
\hline 19 & 52.35 & 0.23 & 0.591 & 0.633333 & -0.04233 \\
\hline 20 & 55.04 & 0.50 & 0.6915 & 0.666667 & 0.024833 \\
\hline 21 & 57.74 & 0.77 & 0.7794 & 0.766667 & 0.012733 \\
\hline 22 & 57.74 & 0.77 & 0.7794 & 0.766667 & 0.012733 \\
\hline 23 & 57.74 & 0.77 & 0.7794 & 0.766667 & 0.012733 \\
\hline 24 & 60.43 & 1.04 & 0.8485 & 0.866667 & -0.01817 \\
\hline 25 & 60.43 & 1.04 & 0.8485 & 0.866667 & -0.01817 \\
\hline 26 & 60.43 & 1.04 & 0.8485 & 0.866667 & -0.01817 \\
\hline 27 & 63.13 & 1.31 & 0.9019 & 0.933333 & -0.03143 \\
\hline 28 & 63.13 & 1.31 & 0.9019 & 0.933333 & -0.03143 \\
\hline 29 & 68.52 & 1.85 & 0.9678 & 1 & -0.0322 \\
\hline 30 & 68.52 & 1.85 & 0.9678 & 1 & -0.0322 \\
\hline & & & & & \\
\hline
\end{tabular}

From the calculation results as in table 4 obtained the highest difference which is the result of L observations (Lo) of 0.14903 Based on the criteria value or the value of the $\mathrm{L}$ table $\left(\mathrm{L}_{\text {tab }}\right)$ at $\alpha=0.05$ with $\mathrm{n} ; 30$ found $\mathrm{L}_{\text {tab }}=0.1610$. This fact shows that $\mathrm{L}$ observation is smaller than $\mathrm{L}$ table or in other words $\mathrm{Lo}=0.14903<\mathrm{L}_{\mathrm{tab}}=0.05$.

In accordance with the testing criteria; accept $\mathrm{H}_{\mathrm{o}}$ if $\mathrm{L}_{\mathrm{o}} \leq \mathrm{L}_{\mathrm{tab}}$, where the formulation of the null hypothesis $(\mathrm{Ho})$ is a sample coming from a normally distributed population. Thus based on the test criteria it can be concluded that the arm power data representing the sample in this study came from normally distributed populations.

\section{b. Linearity Testing}

Estimating the Linear Regression Equation between $\mathrm{X}_{1}$ and $\mathrm{Y}$

The intended linear regression equation;

$\hat{Y}=a+b X_{1}$

Where;

$$
\begin{aligned}
\mathrm{a} & =\frac{\left(\sum \mathrm{Y}\right)\left(\sum \mathrm{X}_{1}^{2}\right)-\left(\sum \mathrm{X}_{1}\right)\left(\sum \mathrm{X}_{1} \mathrm{Y}\right)}{\mathrm{n}\left(\sum \mathrm{X}_{1}^{2}\right)-\left(\sum \mathrm{X}_{1}\right)^{2}} \\
& =\frac{(1500,75)(77929,2)-(1500,27)(76168,8)}{30(77929,2)-(2250810,073)}
\end{aligned}
$$

$116952246,9-114273765,6$ 
$=$

$2337876-2250810,073$

$$
\begin{aligned}
& =\frac{2678481,3}{87065,927} \\
& =30,76 \\
\mathrm{~b} & =\frac{\mathrm{n} \sum \mathrm{X}_{1} \mathrm{Y}-\left(\sum \mathrm{X}_{1}\right)\left(\sum \mathrm{Y}\right)}{\mathrm{n}\left(\sum \mathrm{X}_{1}^{2}\right)-\left(\sum \mathrm{X}_{1}\right)^{2}} \\
& =\frac{30(76168,8)-(1500,27)(1500,75)}{30(77929,2)-(2250810,073)} \\
& =\frac{2285064-2251530,203}{2337876-2250810,073} \\
& =\frac{33533,797}{87065,927} \\
& =0,38
\end{aligned}
$$

Thus the linear regression equation becomes;

$\hat{\mathrm{Y}}=\mathrm{a}+\mathrm{bX}_{1}$

$\hat{Y}=30,76+0,38 \quad X_{1}$

The results of the linear regression equation between arm muscle strength (X1) with the ability to shoot $(\mathrm{Y})$ ie $\hat{\mathrm{Y}}=30.76+0.38 \mathrm{X} 1$, can give meaning if there is an increase in arm power then the ability to put a shot put is increasing. Finally, we can conclude that the power power variable associated with shot put capability has linear data.

\section{Estimating the Linear Regression Equation between $X_{2}$ and $Y$}

The intended linear regression equation;

$\hat{Y}=\mathrm{a}+\mathrm{bX}_{2}$

Where;

$$
\begin{aligned}
\mathrm{a} & =\frac{\left(\sum \mathrm{Y}\right)\left(\sum \mathrm{X}_{2}^{2}\right)-\left(\sum \mathrm{X}_{2}\right)\left(\sum \mathrm{X}_{2} \mathrm{Y}\right)}{\mathrm{n}\left(\sum \mathrm{X}_{2}{ }^{2}\right)-\left(\sum \mathrm{X}_{2}\right)^{2}} \\
& =\frac{(1500,75)(77990)-(1500,88)(76555,4)}{30(77990)-(2252640,774)} \\
& =\frac{117043492,5-114900468,8}{2339700-2252640,774}
\end{aligned}
$$




$$
\begin{aligned}
& =\frac{2143023,7}{87059,226} \\
\mathrm{a} & =24,62 \\
\mathrm{~b} & =\frac{\mathrm{n} \sum \mathrm{X}_{2} \mathrm{Y}-\left(\sum \mathrm{X}_{2}\right)\left(\sum \mathrm{Y}\right)}{\mathrm{n}\left(\sum \mathrm{X}_{2}^{2}\right)-\left(\sum \mathrm{X}_{2}\right)^{2}} \\
& =\frac{30(76555,4)-(1500,88)(1500,75)}{30(77990)-(2252640,774)} \\
\mathrm{b} & =\frac{2296662-2252445,66}{2339700-2252640,774} \\
\mathrm{~b} & =\frac{44216,34}{87059,226} \\
& =0,51
\end{aligned}
$$

Thus the linear regression equation becomes;

$$
\begin{aligned}
\hat{\mathrm{Y}} & =\mathrm{a}+\mathrm{bX}_{2} \\
& =24,62+0,51 \mathrm{X}_{2}
\end{aligned}
$$

The results of the linear regression equation between balance (X2) with the ability to reject bullets $(\mathrm{Y})$ namely $\hat{\mathrm{Y}}=24.62+0.51 \mathrm{X} 2$, can give meaning if there is an increase in balance the ability of shot put is increasing. Finally, we can conclude that the balance variable is related to the ability to reject linear data bullets.

\section{c. Research Hypothesis Testing}

Analysis of the Relationship X1 with Y

To test the relationship between arm X1 and Y arm power, the following steps can be carried out;

a) Hypothesis Formulation

Ho: $\operatorname{rx} 1 \mathrm{y}=0$ (There is no relationship between $\mathrm{X} 1$ and $\mathrm{Y}$ )

Ha: $r x 1 y>0$ (There is a relationship between X1 and Y)

b) Significant level: $\alpha=0.05$

c) Test statistics:

$$
\operatorname{rx}_{1} \mathrm{y}=\frac{\mathrm{n} \sum \mathrm{X}_{1} \mathrm{Y}-\left(\sum \mathrm{X}_{1}\right)\left(\sum \mathrm{Y}\right)}{\sqrt{\left\{\mathrm{n} \sum \mathrm{X}_{1}^{2}-\left(\sum \mathrm{X}_{1}\right)^{2}\right\}\left\{\mathrm{n} \sum \mathrm{Y}^{2}-\left(\sum \mathrm{Y}\right)^{2}\right\}}}
$$

d) Testing criteria;

Accept Ho if rob $<\mathrm{rtab}(\alpha ; n)$

e) Data Computing

Based on test statistics and data prices in table 1 above, the magnitude of the value of rob can be calculated as follows.

$$
30(76168,8)-(1500,27)(1500,75)
$$




$$
\begin{aligned}
\operatorname{rx}_{1 y} & =\frac{2285064-2251530,203}{\sqrt{\{30 \mathrm{x} 77929,2-2250810,073\}\{30 \mathrm{x} 77983,7-2252250,563\}}} \\
\operatorname{rx}_{1} \mathrm{y} & =\frac{33539,797}{\sqrt{\{2337876-2250810,073\}\{2339511-2252250,563\}}} \\
\operatorname{rx}_{1 y} & =\frac{33539,797}{\sqrt{\{87065,927\}\{87260,437\}}} \\
\operatorname{rx}_{1} \mathrm{y} & =\frac{33539,797}{87163,127} \\
\operatorname{rx}_{1} \mathrm{y} & =0,3847 \text { (rounded off) } \\
& =0,38 \text {. }
\end{aligned}
$$$$
2285064-2251530,203
$$$$
\operatorname{rx}_{1} \mathrm{y}=\frac{33539,797}{\sqrt{\{87065,927\}\{87260,43} 7\}}
$$

f) Conclusions of Analysis X1 with Y

Calculation results obtained by $\mathrm{r}$ observation of rob $=0.38$ when compared with $\mathrm{r}$ table $(\mathrm{n} ; \alpha=$ 0.05 ) obtained $\mathrm{rtab}=0.361$. From these results it shows that the value of rob $=0.38>\mathrm{rtab}$ value $=0.361$, this means that $\mathrm{Ho}$ is rejected and $\mathrm{Ha}$ is accepted, which states that there is a relationship between arm power (X1) and shot put capability (Y).

\section{Analysis of the Relationship X2 with Y}

To test the relationship between X2 and Y balance, the following steps can be carried out;

a) Hypothesis Formulation

Ho: $\mathrm{rx} 2 \mathrm{y}=0$ (There is no relationship between $\mathrm{X} 2$ and $\mathrm{Y}$ )

Ha: $\operatorname{rx} 2 y>0$ (There is a relationship between $\mathrm{X} 2$ and $\mathrm{Y}$ )

b) Significant level: $\alpha=0.05$

c) Test statistics:

$$
\operatorname{rx}_{2} \mathrm{y}=\frac{\mathrm{n} \sum \mathrm{X}_{2} \mathrm{Y}-\left(\sum \mathrm{X}_{2}\right)\left(\sum \mathrm{Y}\right)}{\sqrt{\left\{\mathrm{n} \sum \mathrm{X}_{2}^{2}-\left(\sum \mathrm{X}_{2}\right)^{2}\right\}\left\{\mathrm{n} \sum \mathrm{Y}^{2}-\left(\sum \mathrm{Y}\right)^{2}\right\}}}
$$

d) Testing criteria

Accept $\mathrm{Ho}$ if rob $<\mathrm{rtab}(\alpha ; \mathrm{n})$

e) Data Computing

Based on test statistics and data prices in table 1 above, the magnitude of the value of rob can be calculated as follows.

$$
\begin{aligned}
& \operatorname{rx}_{2} \mathrm{y}=\frac{30(76555,4)-(1500,88)(1500,75)}{\sqrt{\{30(77990)-(2252640,774)\}\{30(77983,7)-(2252250,563)\}}} \\
& \operatorname{rx}_{1} \mathrm{y}=\frac{2296662-2252445,66}{\sqrt{\{2339700-2252640,774)\{2339511-2252250,563\}}} \\
& \operatorname{rx}_{1} \mathrm{y}=
\end{aligned}
$$




$$
\begin{aligned}
\operatorname{rx}_{1} y & =\frac{44216,34}{\sqrt{759682610}} \\
\operatorname{rx}_{1} y & =\frac{44216,34}{87159,77} \\
& =0,5073 \\
& =0,51
\end{aligned}
$$

f) Conclusion of Analysis X2 with Y

The calculation results obtained by $\mathrm{r}$ observation of $\mathrm{rob}=0.51$ when compared with $\mathrm{r}$ table $(\mathrm{n} ; \alpha=0.05)$. Obtained by rtab $=0.361$. From these results indicate that the value of rob $=$ $0.51>$ rtab value $=0.361$ this means that $\mathrm{Ho}$ is rejected and $\mathrm{Ha}$ is accepted which states that there is a relationship between balance (X2) with the ability to reject bullets (Y).

\section{Analysis of the Relationship between X1 and X2}

To test the relationship between arm power (X1) and balance (X2), the following steps can be carried out;

g) Hypothesis Formulation

Ho: $\mathrm{rx} 1 \mathrm{x} 2=0$ (There is no relationship between $\mathrm{X} 1$ and $\mathrm{X} 2$ )

Ha: $r x 1 y>0$ (There is a relationship between X1 and X2)

h) Significant level: $\alpha=0.05$

i) Test statistics:

$$
\operatorname{rx}_{1 \times 2}=\frac{n \sum \mathrm{X}_{1} \mathrm{X}_{2}-\left(\sum \mathrm{X}_{1}\right)\left(\sum \mathrm{X}_{2}\right)}{\sqrt{\left\{\mathrm{n} \sum \mathrm{X}_{1}^{2}-\left(\sum \mathrm{X}_{1}\right)^{2}\right\}\left\{\mathrm{n} \sum \mathrm{X}_{2}^{2}-\left(\sum \mathrm{X}_{2}\right)^{2}\right\}}}
$$

j) Testing criteria;

Accept $\mathrm{Ho}$ if rob $<\mathrm{rtab}(\alpha ; \mathrm{n})$

k) Data Computing

Based on test statistics and data prices in table 1 above, the magnitude of the value of rob can be calculated as follows.

$$
\begin{aligned}
& \operatorname{rx}_{1} x_{2}=\frac{30(74910,5)-(1500,27)(1500,88)}{\sqrt{\{30 \times 77929,2-2250810,073\}\{30 \times 77990-2252640,774\}}} \\
& \operatorname{rx}_{1 x_{2}}=\frac{2247315-2251725,238}{\sqrt{\{87065,927\}\{87059,226\}}} \\
& \mathrm{rx}_{1 \times 2}=\frac{4410,238}{\sqrt{7579892216}} \\
& \mathrm{rx}_{1 \times 2}=\frac{4410,238}{87062,576}
\end{aligned}
$$




$$
\begin{aligned}
& =0,0506 \\
& =0,05 \text { (rounded off) }
\end{aligned}
$$

\section{1) Conclusions of Analysis X1 with $\mathrm{X} 2$}

The calculation results obtained by $\mathrm{r}$ observation of rob $=0.05$ when compared with $\mathrm{r}$ table $(\mathrm{n} ; \alpha=0.05)$ obtained $\mathrm{rtab}=0.361$. From these results indicate that the value of rob $=$ $0.05>\mathrm{rtab}$ value $=0.361$ means that $\mathrm{Ho}$ is rejected and $\mathrm{Ha}$ is accepted which states that there is a relationship between arm power (X1) and balance (X2).

\section{Analysis of the Relationship of X1 and X2 with Y}

The multiple correlation coefficient test is intended to test whether there is a significant relationship between arm power (X1) and balance (X2) together with the ability to put a shot put (Y) on students of SMP Negeri I Tondano. For the purposes of this analysis, please follow the following test steps.

a) Hypothesis Formulation

Ho: Ryx $1 \times 2=0$ (There is no significant relationship between $\mathrm{X} 1$ and $\mathrm{X} 2$ together with $\mathrm{Y}$ )

Ha: Ryx1x2 $\neq 0$ (There is a significant relationship between X1 and X2 together with $\mathrm{Y}$ )

b) Significant level $\alpha=0.05$

c) Testing criteria

Reject Ho if Fhit $>$ Ftab $(\mathrm{F} \alpha(\mathrm{k}, \mathrm{n}-\mathrm{k}-1)$ or

Thank Ho if Fhit $\leq$ Ftab

d) Test statistics

$$
R_{y} x_{1} x_{2}=\sqrt{\frac{r^{2} y_{1}+r^{2} \mathrm{yx}_{2}-2 \operatorname{ryx}_{1} \cdot \operatorname{ryx}_{2} \cdot \operatorname{rx}_{1} x_{2}}{1-r^{2} x_{1} x_{2}}}
$$

The significance test of the multiple correlation coefficient $(\mathrm{Ry})$ is as follows;

$$
F_{\text {hit }}=\frac{\mathrm{R}^{2} / \mathrm{k}}{\left(1-\mathrm{R}^{2}\right) / \mathrm{n}-\mathrm{k}-1}
$$

e) Data Computing

Based on test statistics and the amount of data or data prices in table 1 above and the help of Calculator Casio fx 3600p, the value of Ry and Fhit can be obtained as follows.

Known correlation coefficient values;

$\mathrm{rx} 1 \mathrm{y}=0.38$

$\mathrm{rx} 2 \mathrm{y}=0.51$

$\mathrm{rx} 1 \mathrm{x} 2=0.05$

with the multiple correlation test statistical formula used, the multiple correlation coefficient can be calculated as follows;

$$
\begin{aligned}
\mathrm{R}_{\mathrm{y} \mathrm{x}_{1} \mathrm{x}_{2}} & =\sqrt{\frac{(0,38)^{2}+(0,51)^{2}-2(0,38)(0,51)(0,05)}{1-(0,05)^{2}}} \\
& =\sqrt{\frac{0,38512}{0,9975}} \\
& =0,6213 \\
& =0,62 \text { (rounded off) }
\end{aligned}
$$

The significance of the multiple correlation coefficient can be calculated by the equation the following.

$$
(0,62)^{2} / 2
$$


$\mathrm{F}_{\text {hit }}=$

$$
\begin{gathered}
1-(0,62)^{2} / 30-2-1 \\
0,1922
\end{gathered}
$$

$=$

0,0228

$=8,43$

f) Interpretation of Ry and Fhit values

From the results of the calculation of the double correlation coefficient, the magnitude of $\mathrm{Ry}=0.62$ with the coefficient of determination of the double correlation is $\mathrm{R} 2=0.3844$. From this result, it can be predicted the significance of the multiple correlation coefficient, where the results achieved by Fhit $=8.43$ are far greater than F table or Ftab $(0.05 ; \mathrm{k}, \mathrm{nk}-1)=3.35$. Thus based on testing criteria, reject Ho and accept Ha.

g) Conclusions of X1 and X2 analysis with $\mathrm{Y}$

From the results of calculations and based on testing criteria, it can be concluded that reject Ho and accept Ha stating that there is a significant relationship between arm power (X1) and balance (X2) together with the ability to put a shot put $(\mathrm{Y})$ on junior high school students Negeri I Tondano.

\subsection{Discussion}

\section{a. Arm muscle strength (X1) with Shooting Y ability}

Based on the results of calculations with the product moment correlation test statistics it turns out that between the arm powers with the ability to reject shot on junior high school students I of Tondano. There is a linear relationship, with a linear regression equation $\hat{Y}=30.76$ $+0.38 \mathrm{X} 1$. This means that if there is an increase in arm power, the ability to reject shot in Junior High School students I of Tondano will increase or increase by 0.38 units.

From the results of testing the correlation coefficient obtained by rx1y or rob $=0.38$ with the magnitude of the coefficient of determination $r 2=0.1444$, this means that arm power can contribute or contribute to the variation of shot put on Junior High School students I of Tondano by 14.44 percent, while the remaining 85.66 percent is caused by external factors.

\section{b. Balance (X2) with Bullet Resistance Y}

Based on the results of calculations with the product moment correlation test statistics it turns out that between the balance with the ability to reject shot on the Junior High School students I of Tondano there is a linear relationship, with a linear regression equation $\hat{Y}=24.64$ $+0.51 \mathrm{X} 2$. This means that if there is an increase in equilibrium, the ability to put a bullet on Junior High School students I of Tondano will increase or increase by 0.51 units.

From the calculation results by testing the correlation coefficient obtained by rx $2 y$ or rob $=0.51$ with the magnitude of the coefficient of determination $\mathrm{r} 2=0.26 .01$ this means that the balance can contribute or contribute to the variation of the ability of shot put on Junior High School students I of Tondano by 26, 01 percent, while the rest of 73.99 percent is caused by external factors.

\section{c. Arm power (X1) and balance (X2) with Y shot put capability}

From the results of linearity testing between arm power (X1) and balance (X2) with the ability to reject bullets $(\mathrm{Y})$ in Junior High School students I of Tondano that have been proven before, then together if there is an increase in arm power and balance will also increase the ability shot put on Junior High School students I of Tondano. 
Based on the results of calculations using multiple correlation test statistics or multiple correlation it turns out that between the power of the arm and balance together with the ability to reject bullets in Junior High School students I of Tondano there is a relationship of Ryx $1 \times 2=$ 0.05 with the magnitude of the coefficient of determination $\mathrm{R} 2=0.0025$ means that arm power and balance can jointly contribute or contribute to the variation of the ability to reject bullets in Junior High School students I of Tondano by 00.25 percent, while the remaining 99.75 percent are caused by external factors. Possible external factors may include arm muscle strength, initial speed and wrist flexion. This result has been strengthened by a significant test of multiple correlation coefficients, which is proven that arm power and balance together the ability to resist shot in Junior High School students I of Tondano have a significant correlation coefficient.

\section{Conclusion}

Based on the results of research and discussion, some conclusions can be drawn as follows: 1) There is a relationship between nutritional status with learning outcomes of physical, sports and health education in Junior High School students I of Tondano; 2) There is a relationship between physical freshness with learning outcomes of physical, sports and health education in Junior High School students I of Tondano; 3) There is a relationship between nutritional status and physical freshness together with learning outcomes of physical, sports and health education in Junior High School students I of Tondano.

\section{References}

Anonim. (2008). Buku Pedoman Biomekanika dan Kebugaran Jasmani. Kementerian Negara Pemuda Dan Olahraga Republik Indonesia Deputi Bidang Peningkatan Prestasi Dan Iptek Olahraga Pusat Pengembangan Ilmu Pengetahuan Dan teknologi Dan Kesehatan Olahraga Nasional. Jakarta.

Anonim. (1993). Pedoman Pengaturan Makanan Atlet. Departemen Kesehatan Republik Indonesia. Direktorat Jenderal pembinaan Kesehatan Masyarakat dire ktorat Bina Upaya kesehatan Puskesmas.Jakarta.

Abdullah, A. (2003). Pendidikan Jasmani dan Olahraga di Lembaga Pendidikan Menengah dan Tinggi. Perkembangan Olahraga Terkini. Kajian Para Pakar. Jakarta: PT Rajagrafindo Persada.

Ateng, A. (1999). Olahraga di Sekolah. Jakarta: PT. Rajagrafindo Persada

Giriwijoyo, S., Komariyah, L. (2012). Ilmu Kesehatan Olahraga. Bandung: PT.Remaja Rosdakarya.

Kuntaraf, J., Kuntaraf, K. (1992). Olahraga Sumber Kesehatan. Bandung: Advent Indonesia.

Ngurag Nala. (1998) Pelatiban Fisik Olabraga. Purwakarta, Denpasar.

Nurhasan, (2001). Tes dan Pengukuran dan Pendidikan Jasmani. Jakarta: Depdiknas.

Mien K. Mahmud et al. (1990). Komposisi Zat Gizi Pangan lndonesia - Depkes.

Sayoto. (1988). Pembinaan Kondisi Fisik Dalam Olahraga. Semarang: FPOK IKIP Semarang.

Sadoso sumosarjuno, 1996. Olabraga Dan kesehatan. Pustaka kartini, Jakarta

Sharkey, B., J. (2003). Kebugaran Kesehatan. Divisi Buku Sport.Jakarta : PT Rajagrafindo Persada.

Soekarman. (1995). Tujuan Berolahraga dan Pendidikan Jasmani. Surabaya : Seminar sehari Wanita dan Olahraga.

Soetjiningsih. (1995). Tumbuh Kembang Anak. Jakarta: Penerbit Buku Kedokteran.

Sugiyono. (2003). Peranan Pendidikan jasmani dan Olabraga di Sekolah Dasar sebagai Landasan Pembinaan dan pengembangan Keolabragaan Nasional.Jakarta : PT Rajagrafindo Persada. 